\title{
Lexical-Semantic Fields Due to Word-Formation in Synonymic Adverbs; Affixes Fields
}

\author{
Manjola Zaçellari \\ "Aleksander Moisiu" University of Durres, Albania \\ E-mail:manjola_zacellar@yahoo.com \\ Ledjana Beshaj \\ "Aleksander Moisiu" University of Durres, Albania
}

Doi:10.5901/ajis.2012.v2n4p293

\begin{abstract}
:
Studies and different analysis in lexical semantic field are also compiled via lexical and semantic fields. In fact, nowadays none of the studies can be done without this method, set by Jost Trier. These fields can also be traced from a very interesting angle, that of word-formation. This constitutes the aim of our work; to see these fields due to word-formation at synonymic adverbs. Mainly, we are focused on the affixes formations, because the affixes derived adverbs is a very rich class in Albanian language, also at conversion, compound and composed formations. Thus, the words are seen according to tantamount, exception, contraposition, inclusion relations etc. We are interested in studying the synonymy in the adverbs formed by these affixes: alb: -isht -thi, as / -azi, shëm, -t(ë), -a, -aj, -sh, -çe. Thus, inside one word we can do groupings according to affixes fields. For example, at the word blindly (alb: verbërisht) we can distinguish these fields: a. the affix field of the units formed with the suffix -as (-azi): alb: verbas (verbazi); qorras (qorrazi); symbyllurazi; $b$. The affix field of the units formed with the suffix -thi: alb: symbyllthi; qorrthi; c. the affix field of the units formed with the suffix -shëm: alb: verbueshëm; the field of other affixes, derived or not, as: alb: kuturu, symbyllur, symbyllti. he adverbs formed with compound also form a large word-formation field. While, the word-formation field of adverbs formed with composition is smaller. The interpreted material is harvest from Albanian Synonymic Dictionary (2004).
\end{abstract}

\section{Introduction}

In Albanian language the adverbs are a well studied class. This class is not only represented in early grammars, but is also treated from different angles as semantic, functional, word-formation etc. The synonymy is also studied as well. Literary developed languages are very rich with synonyms. If the languages are very developed, they are very flourishing, complicated and very rich of synonyms (Islamaj Shefkie, 1985). The Albanian language is one if these languages.

\section{Synonymy}

In general, synonymy is accepted as one of the most important semantic systems, even in the first part of twentieth century, in American linguistics we find statements as the one of L. Bloomfield that doesn't accept the existence of (real) lexical synonymy in language: According to him (1933) every linguistic form has a specified and defined meaning. Nowadays, this thought is exceeded.

One of the most famous linguists in the field of lexical semantics, John Lions (2001) is focused extensively on the semantic phenomena in language.

He uses the terms complete synonymy and genuine synonymy. He distinguishes four kinds of complete synonymy (genuine and non genuine synonymy): complete synonymy and genuine synonymy; genuine synonymy, but not complete; non genuine synonymy, but not complete; non genuine and non complete synonymy . 
The theory of lingusitic relativism defended by this author is well-known. Even though he accepts the synonymy, he expresses that synonymy denotes meanings report, that is determined by the context in a higher grade that every other semantic report; so the definition in the context is an issue of possibility (Lions John, 2001)

While, W. E Collinson (Islamaj Shefkie, 1985) accepts synonymy and gives importance to distinctive features within synonyms, so to the part that distinguishes them from each other. Thus, exposing a lot of distinctions, he says that is against the complete synonymy.

\section{Synonymic lexical fields}

Semantic fields at adverbs are created by unconditional semantic connections. They are of different dimensions. When observing them we find out that all these adverbs are monosyllabic, that means they are very old and belong to active and general lexicon of Albanian language. Because of their long usage they have so many meanings. The reasons of these capacitive dimensions are treated circumstantially by the linguist V. Memisha (1999). Even though he doesn't speak about the adverbs directly, he mentions that defining the semantic volume of lexical units, is needed to be considered the time when a unit is entered and used, the density of its usage, the source where it comes from, the kind of speech, kind of functional style, where the adverb is displayed, the geographical usage, the relations that this unit elicits in word-formation paradigmatic group, etc.

Usually, non-derived adverbs are very old, and belong to the underlying reserve, to the active general part of the Albanian language lexicon and have a lot of synonyms. As they are in use from a long time, they build sintagmatic semantic relations and paradigmatic ones. That's why they have so many meanings. Let us see some lexical fields: (Note that the examples are in Albanian language due to the specific of our article)

a. minimal synonymic lexical fields, with two or three units:

CÉKASH ndajf. Mënyrë të luajturi në grup, në të cilin njëri ndjek të tjerët për t'i cekur. Cikas.

FAMILJARÍSHT ndajf. Me tërë familjen. Fëmijërisht. U nis për t'u shpërngulur fëmijërisht në Korçë, po fshatarët e kanë lutur të qëndrojë dhe e kthyen. (Let. art.).

GRÓPTHI ndajf. Mënyra e të luajturit gropëqiqër. Gropëqiqër.

ANASJÉLLAS ndajf. Në mënyrë të anasjellë. Ndërsjellas. Dyanësisht në mënyrë të dyanshme. Kjo vlen dyanësisht, si për ne edhe për ju, se sa fitojmë aq edhe humbasim të dyja palët. (Pub.).

ZÝMTË ndajf. Me fytyrë a me vështrim të zymtë. Vrenjtur. Mrrolshëm krahin. Nën vetullat e trasha shihnin mrrolshëm dy sy të thellë. (Let. art.).

b. But, in Albanian language we find lexical fields and many synonymic units. So, we have synonymic lexical fields when the relations are within the semantic structure of the word (when none of the synonyms is brought to the dominant of synonymic row):

GJITHNJË ndajf. 1. Gjatë gjithë kohës. Gjithmonë. Përherë. Ngaherë. Kurdoherë. Ngaherë. Ngaherë ashtu ka qenë. E urtë, e sjellshme, me një fytyrë të ëmbël e të qeshur. (Let. art.). Gjithherë. Se atje kam lindur e jam rritur dhe për atje më rreh zemra gjithherë. (Let. art.). Vazhdimisht. Vijimisht. Vijimisht e pati këshilluar të mos rrinte me të, të mos merrte huqet e tij, të mos i binte pas në paudhësitë. (Let. art.). Përditë. Nisesos bised. Dita-ditës. Dita-ditës po shohim se si po ndryshon faqe kjo qendër pushimi aq e bukur nga natyra. (Pub.). Prore krahin. O, unë / Kurrë s'kam me të heqë / Prej zemre, / Prore kam me u rritë / Me ty / Me ju. (Let. art.). Tejendanë. - Kështu ka qenë tejendanë, si vjet, si sivjet. (Ligj. fol.). Tejembanë. Tejefund. Denbabaden bised. 2. Në çdo kohë, në çdo rast, çdo herë. Gjithmonë. Kurdoherë. Përherë. Ngaherë. - E merr të birin ngaherë me vete, kudo që shkon, edhe për peshk. (Ligj. fol.). Çdoherë. Gjithherë. Se si i bashkoi plotësisht ëndrrat e saj Esmaja me një burrë të ve dhe shumë më të madh se veten, këto mistere natyra nuk i zbulon gjithherë. (Let. art.). 3. Sot e gjithë ditën, pa ndërprerje. Gjithmonë. Përherë. Ende. Kështu plaka u bë e pavdekshme dhe rrojti vetëm në atë kasolle. Ende aty është. (Folk.). 4. si pj. Përdoret në shkallën krahasore të mbiemrave e të ndajfoljeve për të treguar një tipar 
që përforcohet me kalimin e kohës. Gjithmonë. Përherë. Dita-ditës. $E$ shihja time bijë se si rritej $e$ se si bëhej dita-ditës edhe më e bukur. (Let. art.).

HÁPUR ndajf. 1. Në mënyrë që lejon kalimin lirisht; pa kyç. Çelur. Hapët. 2. zakon. fig. Në mënyrë të lirë. Lirisht (kalon). 3. Duke vijuar punën a veprimtarinë. Çelur. Hapët. 4. fig. Drejtpërdrejt, ballë për ballë, pa fshehur asgjë; sy ndër sy; me çiltërsi. Haptas (haptazi). Hapët. Ishte hera e parë që Llazari bisedonte me të kaq hapët për marrëdhëniet e tyre. (Let. art.). Drejt. Drejtpërdrejt. Drejtpërsëdrejti. Sheshit. - Ajo ta tha sheshit se nuk donte të martohej me të. (Ligj. fol.). Sheshas (sheshazi). Fushas. Lakuriq. Çiltas (çiltazi). Qartë. Vetëm atëherë, në ato çaste prove aq të rënda, e kuptoi qartë se me ç'armik kishte të bënte. (Pub.). Aras. Zemërhapur si ndajf. Zemërçelur si ndajf. Açik ndajf. bised. Ndiente për të një admirim. I pëlqente kur e mbronte aq açik. (Let. art.). Ashiqare thjeshtligj. Zbuluar. Beli thjeshtligj. Gjer aty më parë flisje bukur e mirë, tani po e bën beli që je aguridhe. (Let. art.). Dokthi fig. - A do të ta them dokthi? Ja, po ta them: fajin e ke ti. (Ligj. fol.). Shul. Trup fig. Foli shkurt e trup: duhet kjo dhe ajo, në këtë dhe në atë orë. (Let. art.). Rrumbull. Rrumbullak. - Nuk e kishte zor t'ia thoshte rrumbullak të vërtetën në sy. (Ligj. fol.). Ballas (ballazi). Ballëhapur. Zgjeshur. Ballëçelur. Ballafaqe. Faqe. Faqeza. Përfaqe (përfaqez). Publikisht libr. Botërisht. Copë. Troç. Shqip. E dobishme është gjithnjë e vërteta, e drejta e thënë thjesht e shqip. (Let. art.). Shkoqur. lu përgjegj shkoqur se nuk e dashuronte më. (Let. art. përkth.). Cok krahin. - la tha cok, në fytyrë, pa u trembur fare. (Ligj. fol.).

b. 2. We also have two voluminous lexical fields which carry a part of synonyms within the structure (macrosystem), while some carries them to the dominant of synonymic row, out of the semantic structure given in the dictionary.

KEQ ndajf. 1. Me cilësi të dobët, jo ashtu si duket; pa vlerë e me shumë të meta. Ligsht. Lig bised. Dobët. Ndoshta është më dobët me mësime nga i vëllai, që shkëlqen në çdo lëndë. (Let. art.). Lyç. Sallamatas bised. 2. Në mënyrë të pamoralshme, në mënyrë të parregullt. Keqas. Negativisht libr. Ulët. Shëmtuar. Panjerëzisht. 3. Në vështirësi; në gjendje shëndetësore, ekonomike etj. të vështirë. Keqas. Tukeq. Kalaveshas. Zgriptas. Ngushtë. - Ishte ngushtë nga paratë, s'e mbaronte dot shtëpinë atë vit. (Ligj. fol.). Varfërisht libr. Rëndë. Pisk. Ters. Rrokopujë. Zi. - Zi e më zi ka vajtur sivjet, si asnjëherë. As moti nuk na ndihu. (Ligj. fol.). Ligsht. Lig bised. Angësht. Jam angësht, zaten angësht kam qenë edhe më parë. (Ligj. fol.). Shëmtuar. Jam goditur nën sqetull / Për një syskë e për një vetull, / Jam goditur shumë shëmtuar / Për një vajzë që kam kërkuar. (Folk.). Shtarë. Hedhin valle pas avazit të vjetër. Shkurt, e nisin mbarë, e mbarojnë shtarë. (Let. art. përkth.). Përtokë. Shul si ndajf. Kishim mbetë shul edhe për një problem tjetër që $i$ dha zjarr bisedës. (Pub.). Hall si ndajf. - Hall të rrosh, hall të vdesësh. Keq ashtu, keq kështu. (Ligj. fol.). 4. Me zemërim a me inat. Rëndë. - I foli aq rëndë, me fjalë të pista, sa çuni u skuq. (Ligj. fol.). Thartë. - Ti Arsen, këto fjalë flet gjithë ditën dhe pastaj të vjen thartë kur të qortojnë. (Let. art.). Derrçe bised. 5. Në marrëdhënie jo të mira. Keqas. Gjelas (gjelazi) bised. 6. $\rightarrow$ Fort $_{1}$ ndajf. 7. $\rightarrow$ Mbrapsht $n$ dajf. 8. $\rightarrow$ Dosido $_{1}$ ndajf. 9. si em. $\rightarrow$ Dëm,-i̇ $m$.

\section{Synonymic semantic fields}

When talking about the concept of semantic fields, we support the concept of structural linguistics refering to linguistics fields in general. Also, the Albanian linguist J. Thomai (2009) observes these fields due to structural linguistics. According to him, we can describe the semantic fields of every word, starting from different angles: if we start from polysemy, the semantic field will have to consider all meanings of a word in fixed stage of language; if we start from semantic relations of the words, we can do groupings according to the same elements of synonyms, according to opposite elements of antonyms etc.

Refering to this definition, we can find out adverbial synonymic semantic fields reflected on the Albanian Synonymic Dictionary (2004).

Even here we can divide in two big groups: 
a. the goup of synonymic semantic fields related to an adverb, which includes all the meanings of these units, that enter in synonymic relation with this adverb. For example, for the adverb alb: vrenjtur, engl: cloudy the lexical field means all the meanings of the words (in bold), included in the lexical field of this lexeme. This field has 1 (vrenjtur)+32 (adverbs within the synonymic group) $=33$ lexemes. This way, we have a field that implicates the sum of synonymic meanings of all these words (monosemantic or polysemantic).

VRÉNJTUR ndajf. 1. Me re, jo kthjellët (për motin). Vranët. - Qenka vranët sot, ka mundësi të bjerë shi. (Ligj. fol.). Vrerët. Vranshëm. Turbull. Sapo agoi, doli. Qielli dukej turbull dhe frynte erë e tërbuar. (Let. art. përkth.). Mugëll. Ishte mugëll dhe asgjë nuk shihej qartë. (Let. art.). Mugët. Sterrë si ndajf. shumë vrenjtur. 2. fig. Si i zemëruar; me inat. Vranët. Vranshëm. Vrerët. Zymtë. Xha Sadiku ngriti vetullat e tij të trasha dhe më foli duke më vështruar zymtë. (Let. art.). Mahmur bised. U përshëndeta me ta rëndë-rëndë dhe ashtu mahmur siç isha nuk më jepej ta hapja gojën për të thënë ndonjë gjë sa për bisedë. (Let. art.). Mrroltë krahin. Mrrolshëm krahin. Zemërueshëm. Buzëvarur. Buzëvrarë. Fytyrëvrarë. Turivrarë keq. Turivarur keq. Fytyrëngrysur. Fytyrëvrenjtur. Fytyrëzymtë. Vetullngrysur. Vetullvrenjtur. Vetullrrudhur. Vetullarënë. Vetullmrrolur krahin. Ballëvrenjtur. Ballëngrysur. Ballërrudhur. Ballënxirë.

b. When we have a polysemantic adverb it desplays as polysynonymy. So, within its semantic structure, we can find out semantic subfields, related to semantic units of the words that enter in synonymy within a given meaning. For the adverb alb: tërthoras (tërthorazi), engl: sideways we have 5 subfields (as many meanings the word has).

TËRTHÓRAS (TËRTHÓRAZI) ndajf. 1. Në vijën që bashkon dy skaje a dy kënde të kundërta. Tërthor (tërthori). Kryqas. Kryqthi. Kryq si ndajf. Kërthazi. Ai nuk e humbte kohën kot: rripi ish prerë kërthazi, si me thikë. (Let. art. përkth.). Shul. Një plep ishte rrëzuar nga stuhia e natës dhe e kishte zënë udhën shul. (Let. art.). Përshul. Shkarthi. Kithi (për së kithi).

2. Jo drejt, anës e anës. Tërthor (tërthori). Anës. Anësisht. Kërthazi. Përpara u doli një arë, së cilës i ranë kërthazi, pastaj nisën ngjitjen. (Let. art.). Kithi (për së kithi). Larg. Largas (largazi). Zhdrejtazi.

3. fig. Jo drejtpërdrejt, anës e anës. Tërthor (tërthori). Shkaras (shkarazi). Shkarthi. Kalimthi. Ngjarjen që solli aq shumë pështjellim Bimi e përmendi kalimthi e kjo nuk u pëlqeu. (Let. art.). Larg. Muhabetin e solli larg e larg tek ajo vajzë që i kishte mbetur në mendje. (Let. art.). Largas (largazi). Rrëshqitas (rrëshqitazi). Teksa ecnin krah për krah nëpër rrugët që shpien në lagjen e limanit, $i$ kunati ia hodhi fjalën rrëshqitas të thyerit shpirtërisht. (Let. art. përkth.). Rrëshqit. Anësisht. Kemi vënë re se edhe autorë që nuk e kanë pasur çështjen shqiptare në qendër të studimeve të tyre, po mund ta kenë prekur atë anësisht, kalimthi, e kanë zmadhuar rëndësinë e vendimit të 17 dhjetorit. (Pub.). Zhdrejtazi. Qe pra se mësimi i historis së natyrës i ban gjuhës amtare zhdrejtazi shërbime fort të mëdha. (Pub.). Kërthazi. Oficeri ia hodhi edhe një herë fjalën kërthazi, si me mosbesim e droje. (Let. art.). Kithi (për së).

4. $\rightarrow$ Pjerrtas (Pjerrtazi) ndajf.

5. edhe fig. $\rightarrow$ Shtrembër 1 ndajf., edhe fig.

\section{Synonymic adverbs}

As other parts of speech the adverbs enter in synonymic relations with each-other. When studying these synonymic adverbs due to lexical-semantic fields, we discover very interesting phenomena, especially of the lexical-semantic fields of adverbs, formed by the suffixes (in Albanian) -isht, -thi, as / -azi, -shëm, -t(ë), -a, aj, -sh, -çe.

The Albanian adverbs in general and others that enter in synonymic relations with each other are derived and not derived. 
Not derived adverbs are the kind of adverbs that in nowadays point of view aren't indissoluble (Albanian Language Grammar, 2002), as near, bad, well, down, behind, above (alb: afër, keq, larg, mirë, poshtë, prapa, lart) etc.

These adverbs enter in synonymic relations with derived and not derived adverbs. For example for the adverb well, alb: mire we have: alb: ashtu, paq, bukur, drejt, fort, tej etc. and miras, mbarë, bujarisht, përzemërsisht, drejtas, tumirë, mirë (e) etc. As shown at the examples below:

MIRË ndajf. 1. Ashtu si duhet, pa të meta. Tamam. Ashtu. Paq bised. Bukur. Sa bukur dinte të bënte dallimin ndërmjet dashurisë e urrejtjes. (Let. art.). Drejt (flet). Fort. Tej (më). Pupa fig. bised. 2. Me bujari; me dashuri. Miras. Mbarë. Bujarisht. Përzemërsisht. Drejtas. - Shkonim drejtas me komshinjtë, asnjë llaf të keq nuk kemi këmbyer. (Ligj. fol.). 3. Në gjendje të mirë e të këndshme. Rehat. Gjatë këtyre ditëve ai u mësua të rronte rehat, me gjithë të mirat. (Let. art.). Tumirë. 4. si em. $\rightarrow$ Mir/ë,-a (e) ${ }_{1} f$.

Derived adverbs are the adverbs formed by derivation. (In the Albanian language grammar within the derivation of adverbs are also included affixation, conversion and compound, while at the chapter of wordformation these are three different modes of word-formation (Albanian Language Grammar, 2002).

Affixes derived adverbs are a very rich class in Albanian language. The Albanian linguist, Jani Thomai, has seen some paradigmatic groups with the main suffixes (Thomai Jani, 2004), groups that organised by the suffixes turn into word-formation affixes fields. The main element that organises these fields is the specialized affix, which brings a lot of modifications, first of all semantic modifications.

According to him, "The specialization of the affixes in Albanian language constitutes a very important factor for the creation of semantic models in derived word-formation, and for categorical formations in general. The affixes specialization is accomplished mainly when they come out with different themes, but with the same modified value and first of all this is a semantic specialization" (Thomai Jani, 2004).

As Thomai (2004) formulates that "all words formed with a suffix in synchronic plane form an affix field" we can also find a lot of affixes fields at the adverbs with synonymic relations. So the fields turn into lexicalsemantic affixes fields.

Based on the fact that the same author (2004) has seen 8 paradigmatic adverbs groups organised by respective suffixes we are going to trace the synonymy of the adverbs formed with these suffixes.

\section{Adverbs with the suffix -as /-azi}

The adverbs create lexical fields organized by basal meaning, but also by the affix that took part in their formation. But, when we refer to the Synonymic Dictionary (2004) we see that lexical-semantic field involves not only adverbs with the suffixes -as / -azi. This is explained with the fact that the adverbs of this paradigmatic group also have other elements in their semantic structure. We can illustrate this with the example below:

FÝTAS (FÝTAZI) ndajf. 1. Duke u kapur për fyti me dikë; grykë më grykë. Fytafyt. Fytafytas (fytafytazi). Rroku, të cilit i ishte prishur pushka, iu hodh ushtarit serb, që nuk e kishte mendjen tek ai dhe u kap fytafyt me të. (Folk.). Fytthi. Grykas (grykazi). Grykafytas (grykafytazi). Grykagrykas (grykagrykazi). Kacafytas. Kacafytas ndër llogoret / ... Ndeshin shqipet me taborret / E barbarit Turgut Pashë. (Let. art.). Veshas. 2. fig. Duke u grindur vazhdimisht. Fytazi. Fytafyt. Fytafytas (fytafytazi). Grykas (grykazi). Grykafytas (Grykafytazi). Grykagrykas (grykagrykazi). Fytthi. Kacafytas. Grykë si ndajf. 3. Deri në fyt (kur kemi shumë punë). Fytafyt. Fytafytas (fytafytazi). Kacafytas. Grykas (grykazi). Plot.

\section{Adverbs with the suffix -thi}

These types of adverbs refering to Synonymic Dictionary (2004) create word-formation synonymy most with adverbs formed with the suffix -as / -azi.

Example: 
BREZAHÍPTHI ndajf. Mënyrë të luajturi me shumë vetë, nga të cilët disa rrinë përkulur kokë më kokë, të ruajur me brez nga një lojtar, kurse disa të tjerë përpiqen t'u hidhen mbi shpinë. Brezahipas. Brezarojas. Kaladibrançe. Kalorthi (kaluarthi). Hopakalas. Në festat e vitit, për krishtlindje a për pashkë, fëmijët mblidhen e luajnë me arra, me vezë, hopakalas, me litar. (Let. shkenc.). Pelas. Gomarthi bised.

\section{Adverbs with the suffix -isht}

According to the linguist Enver Hysa the adverbs formed with the suffix -(i)sht indicates modality and expresses quality of act, others the intensive character of action and by their meaning they are related with quantity and time adverbs, expressing at the same time various meanings (Hysa Enver, 1970). The adverbs with the suffix -isht enter in synonymic relations with different adverbs. For example:

VERBËRÍSHT ndajf. 1. Duke mos parë fare nga sytë. Verbas (verbazi). Qorras (qorrazi) bised. Shkon qorras, se nuk sheh fare. (Ligj. fol.). Verbueshëm. Qorrthi bised. 2. Pa e shikuar diçka, duke mos parë mirë, si i verbër; me sy mbyllur. Verbas (verbazi). Ecja, pothuaj, verbazi dhe nuk i vija re njerëzit përballë. (Let. art.). Qorras (qorrazi) bised. Qorrthi bised. 3. fig. Symbyllurazi. Symbyllti. Mbyllasyzash. Nuk ka ndërgjegje ajo gazetë që pranon mbyllasyzash sulmet e korrespondentëve krahinorë. (Pub.). Qorras (qorrazi) bised. Qorrthi bised. Kuturu bised. Mua s'para më pëlqen të veproj kuturu. (Let. art. përkth.).

\section{Adverbs with the suffix -shëm}

The adverbs with the suffix -shëm in their essentianl meaning indicates action or state. Here we can have an affix field organised by affixes and within it we have two big subfields, one organised by the basic meaning of manner and the other by the basic menaing of state. For example:

a. VRÚLLSHËM ndajf. Me vrull, në mënyrë të vrullshme. Vrulltas. Hovshëm. Sapo dëgjoi atë lajm, Çeti brofi në këmbë e doli hovshëm nga dhoma. (Let. art.). Hovas. Furishëm me vrull të madh. Turrshëm. Turrthi. Duke ecur ashtu, turrthi, nuk vinte re se ç’kish më të majtë e më të djathtë. (Let. art.). Turravrap me turr e me vrap. Fugas krahin. Vrundull si ndajf. Vrungull si ndajf.

b. GËZÚESHËM ndajf. Me gëzim, gjithë gaz. Hareshëm. Gazmendshëm.

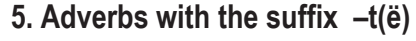

The adverbs formed by the suffix -t(ë), in many cases, but not always create synonymy with the participle verbs with adverbial value, from where the adjectives are formed:

a. RRÁSËT ndajf. Ngjeshur sa nuk nxë më; shumë dendur. Ngjeshur. Atëherë Mehmeti përmendi disa herë punën e tokës, po pastaj ajri i freskët i maleve e bëri të harrojë luginat e ngushta ku njerëzit rronin ngjeshur njëri pranë tjetrit. (Let. art. përkth.). Ngucur ngjeshur shumë pranë njëritjetrit. Mbaj mend fjalën e babait kur më qortonte: "Ç'i shkruan fjalët ngucur!?". (Let. art.).

b. ZBÉHTË ndajf. 1. Pa shumë dritë a shkëlqim. Zbehtas. Mugët. Plaka e vuri kandilin mbi buharin e oxhakut. Poshtë u bë më mugët se më parë. (Folk.). Marrtas. Murrët. Dobët. 2. fig. Pa forcë. Dobët. Flashkët.

\section{Adverbs with the suffixes $-a,-a j$}

The adverbs with the suffix -a and -aj are a small group, "perhaps not a word-formation type..., with meanings and stylistic value and totally popular creations, of colloquialism, some of them are a regional variant" (Thomai Jani, 2004).

As shown on the example below, it is difficult or rather impossible to create affixes fields within these adverbs: 
a. DÉNGËZA ndajf. 1. Plot e përplot, buzë më buzë. Deng si ndajf. Hambarët i kishin deng me flori, o mbret i madh. (Let. art. përkth.). Vandak. Përplot. Plot. 2. $\rightarrow$ Barabar $_{2}$ ndajf.

FÁQEZA ndajf. 1. Duke e parë njëri-tjetrin, sy ndër sy. Faqas. - Me emër njiheshin, po tashti u njohën faqas. (Ligj. fol.). 2. $\rightarrow$ Hapur ndajf. 3. $\rightarrow$ Qartë3 ndajf. 4. $\rightarrow$ Formalisht ndajf. 5. $\rightarrow$ Përballë ndajf. 6. si parafj. $\rightarrow$ Faqe $_{10}$ si parafj.

b. NJËMËZAJ ndajf. 1. $\rightarrow$ Njëfish $_{1}$ ndajf. 2. $\rightarrow$ Njësh $_{1}$ ndajf.

NJËNÁTËZAJ ndajf. bised. $\rightarrow$ Parmbrëmë ndajf.

\section{Adverbs with the suffix -sh}

Within the adverbs with the suffix -sh we find many lexical-semantic fields. Consider three of them:

a. manner of playing: DÓÇASH ndajf. Mënyrë të luajturi me doçe. Doçarrekash. Dokrras. U mësuam që të dy dhe shkonim përditë me pata, bridhnim fushës e luanim dokrras me çomangë marine. (Let. art.). Dokthi. Cakthi. Lopët i fusnim nga drizat e vetë luanim cakthi. (Let. art.). Gicthi. Gungaz. Topgropthi (topagropthi). Guxhas krahin.

b. manner of sharing: NJËSH ndajf. 1. Bashkë me një tjetër a me të tjerë, tek e të pandarë; duke qenë të shkrirë në një njësi të vetme. Bashkë. Tok. Bashku (së). Toku (së). Njëzaj. Ai dhe ne të gjithë ishim njëzaj, / Tashti ai u nda prej nesh. (Let. art.). Njëmëzaj. Mënjëzaj. Një. Trup. U çua trup e gjithë Shqipëria për të mbrojtur vendin. (Pub.). 2. $\rightarrow$ Njëlloj2 ndajf. 3. $\rightarrow$ Njëherësh $_{1}$ ndajf. 4. $\rightarrow$ Bashkë $_{3}$ ndajf. 5. (me parafjalën më). Në një fill, në një pjesë etj. Njëfish. - Bëje perin njëfish, hiqja fijen tjetër, se nuk hyn në gjëlpëryer. (Ligj. fol.). Bitevi bised. - Këpucët e tua nuk duan gjysma, por taban bitevi. (Ligj. fol.).

c. quantity: (herësh, palësh, vëllimesh): DHJETËFÍSH ndajf. Dhjetë herë më shumë. Dhjetëzaj.

\section{Adverbs with the suffixes -çe}

The adverbs with the suffix -çe create a field with many units, where we can distinguish some lexicalsemantic subfields. The field is organised by essential semantic component of manner of action.

FSHÁTÇE ndajf. bised. 1. Së bashku me të gjithë fshatarët. Fshatarçe. Më të dalë të marsit, kur fshatarët e varfër të Trokthit bashkoheshin fshatarçe në punë, i bënin qetë tok dy e nga dy. (Let. art.). Katundisht. I huaji nuk kalon këndej. Kështu kemi vendosur katundisht. (Let. art.). 2. $\rightarrow$ Fshatarçe 1 ndajf. bised.

\section{Lexical-semantic fields formed by conversion}

As we noticed above, we have also seen another word-formation field. This field is formed by the adverbs formed with the change of the lexical-grammatical category (conversion).

Here we have two groups:

1. Nouns that passed to adverbs, loosing this way their forms of inflections and their usage in petrous forms. Consider the examples above:

RRÓTULL ndajf. 1. Në hapësirën nga të gjitha anët afër dikujt a diçkaje; duke i ardhur nga të gjitha anët dikujt a diçkaje. Rrokull. Rrokullimthi. Rrokullim. Rrotullimthi. Qark. Qarkas. Rrumbullak. Vrangull. Torthi. Anës. 2. $\rightarrow$ Rreth ndajf. 3. $\rightarrow$ Përreth ndajf. 4. $\rightarrow$ Anës ndajf.

We notice that the adverb formed by a noun also enters in synonymy with adverbs formed with affixes, but most with adverbs formed by conversion.

It's very interesting observing another field of an adverb as (alb.: kruspull, engl.: crouch), that in the Dictionary (2004) indicates not only the synonymic relations, but also, the process of conversion (nouns that passes to adverbs). This is indicated by the element as adv., alb: si ndajf. 
KRÚSPULL ndajf. 1. Me trup të mbledhur si lëmsh. Lëmsh. Galamsh si ndajf. Grusht si ndajf. Kutullaç. Kakrruk si ndajf. Karrapuc si ndajf. Garravaç si ndajf. Galacu si ndajf. Kukuvriq si ndajf. Truc. Cucërr. Dërrmak si ndajf. Kular si ndajf. Kulaç si ndajf. - Ishte mbështjellë kulaç nga të ftohtët dhe s'e njoha. (Ligj. fol.). Rrumbullak. Top si ndajf. Lëmuq fig. Cucërr krahin. Palmuç. 2. $\rightarrow$ Shuk $_{3}$ si ndajf.

2. The second group is that of the verbs that passed into the class of adverbs. This intends the transition of participle verbs into the class of adverbs. We have found many lexical-semantic fields in these kinds of adverbs. Within them we can do riorganisations due to affixes or due to manners of word-formation. For example:

HÁPUR ndajf. 1. Në mënyrë që lejon kalimin lirisht; pa kyç. Çelur. Hapët. 2. zakon. fig. Në mënyrë të lirë. Lirisht (kalon). 3. Duke vijuar punën a veprimtarinë. Çelur. Hapët. 4. fig. Drejtpërdrejt, ballë për ballë, pa fshehur asgjë; sy ndër sy; me çiltërsi. Haptas (haptazi). Hapët. Ishte hera e parë që Llazari bisedonte me të kaq hapët për marrëdhëniet e tyre. (Let. art.). Drejt. Drejtpërdrejt. Drejtpërsëdrejti. Sheshit. - Ajo ta tha sheshit se nuk donte të martohej me të. (Ligj. fol.). Sheshas (sheshazi). Fushas. Lakuriq. Çiltas (çiltazi). Qartë. Vetëm atëherë, në ato çaste prove aq të rënda, e kuptoi qartë se me ç’armik kishte të bënte. (Pub.). Aras. Zemërhapur si ndajf. Zemërçelur si ndajf. Açik ndajf. bised. Ndiente për të një admirim. I pëlqente kur e mbronte aq açik. (Let. art.). Ashiqare thjeshtligj. Zbuluar. Beli thjeshtligj. Gjer aty më parë flisje bukur e mirë, tani po e bën beli që je aguridhe. (Let. art.). Dokthi fig. - A do të ta them dokthi? Ja, po ta them: fajin e ke ti. (Ligj. fol.). Shul. Trup fig. Foli shkurt e trup: duhet kjo dhe ajo, në këtë dhe në atë orë. (Let. art.). Rrumbull. Rrumbullak. - Nuk e kishte zor t'ia thoshte rrumbullak të vërtetën në sy. (Ligj. fol.). Ballas (ballazi). Ballëhapur. Zgjeshur. Ballëçelur. Ballafaqe. Faqe. Faqeza. Përfaqe (përfaqez). Publikisht libr. Botërisht. Copë. Troç. Shqip. E dobishme është gjithnjë e vërteta, e drejta e thënë thjesht e shqip. (Let. art.). Shkoqur. lu përgjegj shkoqur se nuk e dashuronte më. (Let. art. përkth.). Cok krahin. - la tha cok, në fytyrë, pa u trembur fare. (Ligj. fol.).

\section{Lexical-semantic fields formed by compound}

A large word-formation class is formed by the adverbs with compound. According to Albanian Grammar (2002) we have a lot of types (seven types). Since compound don't form word-formation models, we are displaying just one synonymic field, within it are formed (as in other cases studied above) some wordformation subfields (dominating them formed with compound).

GJITHNJË ndajf. 1. Gjatë gjithë kohës. Gjithmonë. Përherë. Ngaherë. Kurdoherë. Ngaherë ashtu ka qenë. E urtë, e sjellshme, me një fytyrë të ëmbël e të qeshur. (Let. art.). Gjithherë. Se atje kam lindur e jam rritur dhe për atje më rreh zemra gjithherë. (Let. art.). Vazhdimisht. Vijimisht. Vijimisht e pati këshilluar të mos rrinte me të, të mos merrte huqet e tij, të mos i binte pas në paudhësitë. (Let. art.). Përditë. Nisesos bised. Dita-ditës. Dita-ditës po shohim se si po ndryshon faqe kjo qendër pushimi aq e bukur nga natyra. (Pub.). Prore krahin. O, unë / Kurrë s'kam me të heqë / Prej zemre, / Prore kam me u rritë / Me ty / Me ju. (Let. art.). Tejendanë. - Kështu ka qenë tejendanë, si vjet, si sivjet. (Ligj. fol.). Tejembanë. Tejefund. Denbabaden bised. 2. Në çdo kohë, në çdo rast, çdo herë. Gjithmonë. Kurdoherë. Përherë. Ngaherë. - E merr të birin ngaherë me vete, kudo që shkon, edhe për peshk. (Ligj. fol.). Çdoherë. Gjithherë. Se si i bashkoi plotësisht ëndrrat e saj Esmaja me një burrë të ve dhe shumë më të madh se veten, këto mistere natyra nuk i zbulon gjithherë. (Let. art.). 3. Sot e gjithë ditën, pa ndërprerje. Gjithmonë. Përherë. Ende. Kështu plaka u bë e pavdekshme dhe rrojti vetëm në atë kasolle. Ende aty është. (Folk.). 4. si pj. Përdoret në shkallën krahasore të mbiemrave e të ndajfoljeve për të treguar një tipar që përforcohet me kalimin e kohës. Gjithmonë. Përherë. Dita-ditës. E shihja time bijë se si rritej e se si bëhej dita-ditës edhe më e bukur. (Let. art.). 


\section{Lexical-semantic fields formed by composition}

A small word-formation field is created by the adverbs formed with composition. Refering to the Albanian Synonymic Dictionary (2004), within the synonymic field we have many composed units; as word-formation fields at least we have two: the field of composed words and the field of non composed words. The adverbs of this type also have adjective value, so semantically we can distinguish two semantic fields: adverb synonymic field and adjective semantic field. This can be shown on the examples above:

BALLËHÁPUR ndajf. 1. Me ndërgjegje të pastër e me guxim, ballë për ballë, pa u fshehur. Ballëhapët. Ballëçelur. Ballëlart. Ndjeja sikur i kisha jetuar, pak a shumë, çastet e dyshimta, por edhe sikur isha gjer diku i përgatitur për të përballuar ballëlart provën deri në fund. (Let. art.). Hapur. Sheshit. Çiltas (çiltazi). Zemërhapur. Zemërçelur. Serbes bised. 2. si mb. fig. Që e ka ndërgjegjen të pastër e ka guxim në jetë. Faqebardhë. Syqëruar. Në pyeçin shokët për mua, / Ku u vra ku u qëllua, / Mespërmes në kraharuar, / Po me shokë e i gëzuar, / Faqebardhë e syqëruar. (Let. art.). Hapur (i). Krenar. Çiltër (i). Ballëndritur. E me radhë do të doja të më flisje për të tërë, / Për Merhorin tonë të urtë, fjalëmatur, fjalëpakë, / Kosovarin ballëndritur, shpirtdëborë e zemërgjerë ... (Let. art.). Faqelarë.

Adverbial locutions create another field. They are a stable group of words, which semantically and grammatically are equivalent, but not similar with an adverb (Albanian Grammar, 2002).

Since the Albaninan Synonymic Dictionary (2004) has not treated adverbial locutions extensively (we trace just one or two cases), we are not going to observe them in this article.

In conclusion we may say that studying the lexical-semantic fields of the adverbs due to word-formation, we found out many interesting organised groups, according to the suffix that took part in their formation, but also in other formations as them with conversion, compound and composing.

\section{References}

Albanian Academy of Sciences, (2004), Albanian Synonymic Dictionary, Tiranë Islamaj Shefkie, (1985), Synonymy issues in Albanian language, Prishtinë Bloomfield Leon, (1933), Language, New York Lyons John, (2001), Introduction to theoritical linguistics, Tiranë Memisha Valter, (1999), Semantic phenomena during the formation of adjective derived from participles in Albanian language, Gjirokastër

Thomai Jani, (1989), Semantic derivation in Albanian language, Tiranë

Albanian Academy of Sciences,(2002), Albanian Language Grammar 1, Tiranë

Thomai Jani, (2006), Albanian language lexicology, Tiranë

Hysa Enver, (1970), The adverb in nowaday Albanian language

Thomai Jani, (2004), Semantic specialization of adverbs in Albanian language, Tiranë

Thomai Jani, (2004), Lexical-semantic characteristics of adverbs formed by suffixes in Albanian language, Tiranë 
